\title{
THE USE OF TEACHING BRITISH PARLIAMENTARY DEBATE THROUGH ANDROID APPLICATION, VIDEO, AND POWERPOINT PRESENTATION TO IMPROVE THE STUDENTS' SPEAKING SKILLS
}

\author{
Surya Agung Wijaya \\ Vocational High School (SMK) N 2 Salatiga \\ Jl. Parekesit Salatiga, Central Java, Indonesia \\ sawpedia03@gmail.com
}

\begin{abstract}
The researcher conducted the study to increase the students' speaking skills through Android application, video, and PowerPoint Presentation in teaching British Parliamentary Debate. This study answers two questions (1) How is the implementation of teaching British Parliamentary Debate through Android application, video, and PowerPoint Presentation at English Debate Club in SMK N2? (2) To what extent is the improvement of teaching British Parliamentary Debate through Android application, video, and PowerPoint Presentation at English Debate Club in SMK N2 to improve the students' speaking skills?. The research design of this study was Classroom Action Research. It had three cycles. Each cycle consisted of planning, acting, observing, and reflecting. From the study, the researcher could conclude that the implementation of the study improved gradually from cycle 1, cycle 2, and cycle 3. The improvement of the study was showed when the researcher conducted cycle 3. The result of the t-test of cycle 3 was 2.56. Before the impact has not seen by the researcher in the cycle 1 and cycle 2, the result of the t-test of cycle 1 and 2 was 1 . The passing grade was 72, and the target of the passing grade was $85 \%$. The result of the post-test of cycle 3 was $90.91 \%$ from students. They passed the passing grade. The passing grade of cycle 3 was over the target, so the researcher stopped the study. Thus, instruments proved that it could improve the students' speaking skills.
\end{abstract}

Keywords: British Parliamentary Debate, Android, Video, PowerPoint Presentation, Speaking

\section{INTRODUCTION}

Debate is something exists in the daily activities when you are pro or contra with the social problems. It is the real practice of debate. According to Harvey-Smith (2011: 1), debate is a particular form of argument. It is not a way of reconciling differences - that is a misconception. Debate is a way of arbitrating between differences. It means that the debate is not to make agreement between government and opposition teams after the debate. From the debate between government and opposition teams, the audiences and the adjudicators will make a judgment, and they can support government or opposition teams. According to Harvey-Smith (2011: 2) says that Worlds Style is normally termed the British Parliamentary 
(BP) debate, which grew out of the traditions of the United Kingdom Parliament in Westminster and follows some of the conventions of the House of Commons. It means that the British Parliamentary is used by all countries to conduct debate competition. House of Common is like the House of Representative (DPR) in Indonesia, so debate comes from the habit of members of the council. This habit is adopted by the World Universities' Debating Council, and it separates into the world. The researcher explains introduction from three points of view. There are the problems of teaching and learning process of debate, the reason why he try to use Android application, video, and PowerPoint Presentation, and previous studies.

Many problems happen in the teaching and learning process of debate. The problems are not only for the teacher but also for the students. The researcher is the teacher of English Debate Club in SMK N 2 Salatiga. From the experiences of the researcher, when he taught the students on 22 September 2015, the students were still confused with the regulations of debate. They felt difficult on speaking. Some students did not understand about some technical term in debate, for example: case building and rebuttal. In addition, some students did not understand about the jobs for every position in the debate, for example: first speaker from positive or affirmative team needed to define the motion, give argument, and rebut argument. However, some students forgot to define the motion. They just gave arguments about the motion. The students and teacher had practicing debate on 22 September 2015. Most students did not rebut the argument from the opponent team, for example: second speaker form negative team did not rebut the arguments from the first and second speakers of positive team because the debater did not understand or get the points from positive team. The students just gave arguments from his or her point of view. On 7, 14, and 21 January 2016, the teacher and students practiced Asian Parliamentary Debate. In Asian Parliamentary Debate, it used POI, but the students were difficult to give Point of Information (POI). When they joined in the competition, they were less to give POI. Therefore, they lost in the competition. Most of vocational high school students in Indonesia have less speaking proficiencies. English as the foreign language in Indonesia is the one reason of the problems why they feel difficult to speak English. They worry about how to produce the utterances because they do not have habit to use outside the class. They get anxiety to speak English in the class. In their daily life, they use Indonesian or their mother tongue, for example: 
Javanese, Sundanese, etc. From the students' problems, it is a challenge for the teacher to figure it out.

The students were less active and they were confused in the debate. Therefore, the teacher tries to use interactive media and fun activities in his class because it is studentcentered activities. In this era, the teacher cannot reject our technology. The teacher uses the technology as one of media in teaching. According to Crawford (2013: 1) says that information communication technology (ICT) is a powerful tool as it significantly extends people's abilities, and as a learning tool, it is particularly effective. According to Esteras and Fabre (2007: 48) say that at present most of the devices use in ICT systems are multipurpose:

a. Mobile phones can be used as digital cameras or agendas.

b. Printers are also scanners and faxes.

c. Internet, a global network of computers, enable users to exchange files, send emails and surf the Web to find information, take part in e-commerce, etc.

The researcher assume that the teacher in traditional teaching only uses white board as a tool of learning, and the teacher explains the material. The students only listen to the teacher, and they have less activity in the class. It is teacher center. Therefore, the teacher uses ICT to increase the skills of the students. The students are active in the class, so students' center is conducted in the class by the teacher. The teacher is only a facilitator in the class. According to Mustikasari (2014: 10) says that teacher must attend training or workshop session so that they find a suitable strategy of using ICT in a classroom to help students to increase their achievement. It can be informed that the teacher needs to learn using ICT before he uses ICT in his class. To solve the problems of the researcher, he tries to use Android application, video, and PowerPoint Presentation to teach debate in this study. According to Burnette (2010: 14) says that Android is an open source software toolkit for mobile phones that was created by Google and the Open Handset Alliance. According to Darcey and Conder (2010: 7), Android is the first complete, open, and free mobile platform. It means that everyone can be developer of Android, and developer can make his or her own application. Therefore, from the needs of application, right now debaters have debate application to help them. In Indonesia, many people have smartphone using Android system. According to Jose (2015: para 1-5) says that fifty five million people in Indonesia used 
Android in 2015, and the users would increase until sixty five point two million people in 2016. It can be assumed that most of Indonesian students use Android phones to support his or her daily activities. Many applications that can support the teacher and students in teaching and learning process. Therefore, the researcher uses Android application as the media and smart phone as the tool of learning. The researcher tries to know the improvement of using technology in a class for the teacher and students. The teacher always feels difficult to find motions for his students. The students need to control their times when they speak. From "Debate Assistant", this application can give the motions and a time-control management to speak. According to Apeiro (2015: para 1), Debate Assistant has been designed keeping in mind the need for an application that makes conduction of a debate significantly easier. It means that this application designs to help the debaters when they practice debate. The debaters are easy to get motions from this application, and they are easy to monitor their times. The students can learn by themselves. The teacher is not only using Android application, but also he uses video and PowerPoint Presentation. According to Bull and Bell (2010: 2), a video can be recorded on a cell phone, video camera, edited with a cell phone application, and wirelessly uploaded to YouTube. It means that video is a group of picture that it has animation. It is the result of camera. According to Harmer (2001: 292), one of the main benefits of video-making for the students is the chance to display what they have done and get feedback on it from the students and the teachers. According to Arsyad (1997: 48-49) says that the benefit of film or video can complete basic experiences for the students when they read, discus, practice and the others. Therefore, video helps the teacher and students to get information of their performances, and they can get feedback from the video. The students to other students can give commentary for their performances, so the teacher can add commentary at the end of discussion. Video also gives real image or animation from the information, so the students can imagine the information that the teacher gives to them. According to Marcovitz (2012: xvi), PowerPoint is an appropriate multimedia tool for teachers and a powerful addition to a multimedia design class. According to Stephen (2006: 2), PowerPoint is a presentation graphics package. It means that the users can make slide using this software. PowerPoint Presentations also helps the students to get details information of the materials. As cited from Smith (2006: para 2), there are potential benefits of using the PowerPoint presentation included: 

a. Engaging multiple learning styles
b. Increasing visual impact
c. Improving audience focus
d. Providing annotations and highlights
e. Analyzing and synthesizing complexities
f. Enriching curriculum with interdisciplinary
g. Increasing spontaneity and interactivity
h. Increasing wonder

The reason why he adds video and PowerPoint Presentation because Android application does not give detail regulation of British Parliamentary Debate. Therefore, the students can get regulations of debate and evaluation of their performances from videos, and they can get deeper information from PowerPoint Presentation. All media connected each other when it applies in the class using scientific approach. Video uses in observing state, PowerPoint Presentation uses in collecting information state, and Debate Assistant uses in communicating state. The teacher needs to give feedback in the teaching and learning process. According to Harmer (2001: 106-109), there are two kinds to give feedback. There are feedback during accuracy work and feedback during fluency work. The teacher does not only give feedback, but also he needs to give score to the students. In this study, the researcher uses four elements of speaking from different experts. He uses accuracy, fluency, vocabulary, and pronunciation. Those are used in rubric of speaking for this study. It helps the researcher to give score for the students. There are definition of accuracy, fluency, vocabulary, and pronunciation. According to Nunan (2003: 55), accuracy is the extent to which the students' speech matches what people actually say when they use the target language. It means that when the students focus to use right grammar when they produce utterances. According to Nunan (2003: 55), fluency is the extent to which speakers use the language quickly and confidently, with few hesitations or unnatural pauses, false starts, word searches, etc. It means that when the students focus to deliver the message of the conversation. The accuracy is less in fluency because the students speak quickly and confidently, and they focus on the message rather than the accuracy. According to Broughton, Brumfit, Flavell, Hill and Pincas (2003: 72) say that the vocabulary of conversation is often radically different from the written language with which the student is probably more 
familiar. It means that the students use their common vocabularies when they produce utterances. Therefore, the students are easy in arranging ideas. According to Esling and Wong (1983) as quoted by Nation and Newton (2009: 76) say that pronunciation includes the articulation of individual sounds and the distinctive features of sounds like voicing and aspiration, voice-setting features, and stress and intonation. It means that pronunciation can be internal and external factors of the students. It is internal factors because every student has different organ of sounds. Therefore, to produce utterance, some utterances produce in different features of sounds. It is external factors because the students have different mother tongue. Mother tongue gives impact in production of target language.

Table 1 Scoring of Speaking

\begin{tabular}{|c|c|c|c|}
\hline No & Competency & Description & Scores \\
\hline \multirow[t]{5}{*}{1} & \multirow{5}{*}{ Pronunciation } & Many wrong pronunciation & $20-34$ \\
\hline & & Frequent incorrect pronunciation & $35-54$ \\
\hline & & Occasional errors in pronunciation & $55-69$ \\
\hline & & Some errors in pronunciation & $70-84$ \\
\hline & & No errors or minor errors & $85-100$ \\
\hline \multirow[t]{5}{*}{2} & \multirow[t]{5}{*}{$\begin{array}{l}\text { Grammatical } \\
\text { Accuracy }\end{array}$} & $\begin{array}{l}\text { No mastery of utterance } \\
\text { construction }\end{array}$ & $20-34$ \\
\hline & & Major problems in structure & $35-54$ \\
\hline & & Several errors in structure & $55-69$ \\
\hline & & Minor problems in structure & $70-84$ \\
\hline & & $\begin{array}{l}\text { Demonstrates mastery of structure } \\
\text { (few errors) }\end{array}$ & $85-100$ \\
\hline \multirow[t]{5}{*}{3} & \multirow[t]{5}{*}{ Vocabulary } & Little knowledge of English words & $20-34$ \\
\hline & & Frequent errors of word choice & $35-54$ \\
\hline & & Occasional errors in word choice & $55-69$ \\
\hline & & Minor errors in word choice & $70-84$ \\
\hline & & Effective/appropriate word choice & $85-100$ \\
\hline \multirow[t]{3}{*}{4} & \multirow[t]{3}{*}{ Fluency } & Dominated by hesitation & $20-34$ \\
\hline & & Frequent hesitation & $35-54$ \\
\hline & & Occasional hesitation & $55-69$ \\
\hline
\end{tabular}




\begin{tabular}{|l|l|l|l|}
\hline \multirow{2}{*}{} & Minor hesitation & $70-84$ \\
\cline { 3 - 3 } & No hesitation & $85-100$ \\
\hline
\end{tabular}

There were four previous studies. The first previous study came from Aclan and Aziz (2015). In this previous study, it used qualitative case study design. The result of the study got debate as interactive activity that debate gave opportunity for the students to learn new vocabularies.

The second previous study came from Yang and Che (2015). This previous study used Android application as the treatment of the study. The result of the study that all 33 students improved their TOEIC scores showed on their post-test, of which males improved their scores from 538 to 618 and females from 483 to 518.

The third previous study came from Kim (2015). He had study about "Using Authentic Videos to Improve EFL Students' Listening Comprehension”. Regarding from the first research question, the result between the pre- and post-tests, statistically significant differences were found in the intermediate and advanced proficiency groups. However, the students in the low proficiency group did not show any significant differences between the two tests. Regarding from the second research question, the means of the post-test demonstrated a notable distinction. The result said that the students' listening proficiency level was a considerable variable when the teacher would use authentic video materials or not in English listening courses. Regarding from the last research question, the participants generally showed positive attitudes toward using authentic video materials. Analysis of the students' responses from the closed-ended questionnaires showed that there were no significant differences among the three groups. The respondents said that using videos were effective and interesting.

The fourth previous study came from Corbeil (2007). He had a study about using PowerPoint presentations (PPTs) to replace textbooks and blackboards for teaching grammar. Regarding from the first research question, the result was no statistically significant from pretest and post-test between the PPTs groups and the textbook and blackboard groups on any of the three exercises. The first exercise result, t-test was 0.67 . The second exercise result, $t$-test was 0.40 . The third exercise result, t-test was 0.13 . Thus compared with the score of the $t-$ table with $5 \%$ of insignificance. Regarding from the second research question, the positive 
comments were expressed by the students in the experimental group. They said that PPTs helped them in the process of learning because it had highlighting, color coding, different fonts, and visual effects. PPTs were also easy for the students to download and print at home.

From the four previous studies, the researcher saw something difference from his study. From first previous study, the kind of debate was not clear enough using in the class, so the researcher made specific on the British Parliamentary Debate for this study. British Parliamentary Debate was adopted all university in the world, so the result of this study could adopt by all school or university. In addition, the skill was vocabulary, but the researcher tried to increase the challenge into speaking skills. From second previous study, they used Dr.eye. This application included Mandarin, English and Japanese. In this application, the students learned about only language. On the other hand, the researcher used an Android application "Debate Assistant" to help the teacher when he taught the British Parliamentary Debate. This application provided the motions and the times management. From the third previous study, Kim used video to improve the students listening skills, but this study used video to improve the students' speaking skills. From the last previous study, Corbeil used the PowerPoint Presentations to replace textbooks and blackboards for teaching grammar. In this study, the researcher used the PowerPoint Presentations as the media to deliver materials about the British Parliamentary Debate because video and Android application were not enough to explain about the British Parliamentary Debate. From the information given, the researcher could conclude that this study tried to retest some variables of previous studies with the different skills. This study had specific rule rather than previous studies variables. This study is different from previous studies because it uses three variables. It applies in the class using scientific approach. Video uses in observing state, PowerPoint Presentation uses in collecting information state, and Debate Assistant uses in communicating state. The variables connect each other in the teaching and learning process. As a result, the researcher's study is difference to the previous studies.

\section{Research Methodology}

\section{Subject, research design, and cycle of classroom action research}

The subject of the study is the members of English Debate Club in SMK Negeri 2 Salatiga. In 2015 - 2016, the members of EDC came from fifth, sixth, and seventh 
generations. When the researcher conducted the study, only 11 members could join in this study. One member came from fifth generation; one member came from sixth generation and nine members came from seven generation.

In this study, the research design was classroom action research. There were some definitions of action research from experts. According to Lodico, Spaulding, and Voegtle (2006: 282), action research is research conducted by practitioners in their own school setting to identify and take actions to remedy problems that occur in their practice. It means that action research comes from the problems of the teacher when he or she teaches his or her students. Action research helps the teacher to evaluate and get solution of his or her problems in teaching. Therefore, the teacher can improve their ways to teach the students.

In the cycle of classroom action research, according to Kemmis and McTaggart (1988) as quoted by Hopkins (1993: 49), 'Action Research Planner', where a sequential program for the teachers intending to engage in action research is outlined in some detail.

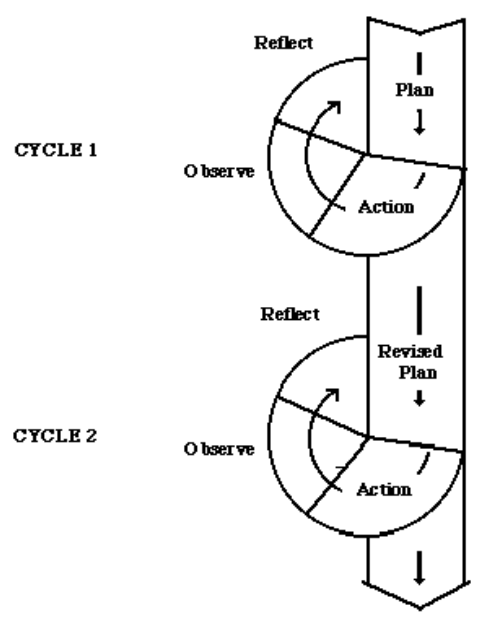

Figure 1 Model of Classroom Action Research

The researcher is the debate trainer of English Debate Club in SMK N 2 Salatiga. In this study, the researcher invited the observer from IAIN Salatiga. He is Faisal Abi Yusuf. The researcher planed the cycle as below.

1. Cycle

\section{a. Planning}

In planning stage, the researcher planned what action would be done. There were activities in the planning. The teacher would prepare syllabus, lesson plan, rubric, material, media, the students' attendance list, the students' scoring list, the 
teacher's and the students' observational checklist. The teacher checked tools of learning in the class. To collect the score of the students, the teacher used flashcards for pre-test and post-test. To analyze the data, the teacher used the camera to take the pictures and videos.

The media used in this study such as the Android application, PowerPoint Presentation, and video. The Android Application was "Debate Assistant", and it used in all cycles. The content of PowerPoint Presentation and video was different for each cycle. Therefore, the preparation was prepared in order to reach the purpose of teaching and learning process.

b. Acting

In acting stage, the researcher did his planning. He used scientific approach. In observing state, he presented a video. In questioning state, he gave opportunity for the students to give question about the video. In collecting information, he gave opportunity for the students to work in groups, and presented PowerPoint Presentation. In associating state, the teacher explained Android application "Debate Assistant" and practiced to operate it. In communicating state, the students practiced the British Parliamentary Debate and used Debate Assistant in the debate. Before the class finished, the teacher gave feedback, reinforcement, and motivation for the students.

c. Observing

The observer observed the researcher how he taught his students. The researcher and observer also observed the students, and it started from pre-test until post-test. They collected the score of the students. The observer used observational checklists to observe the teacher and students.

d. Reflecting

The researcher reflected his lesson plan, evaluated how he taught his students, and calculated scored of his students. The observer gave the data from the observation. When his lesson plan was not effective to teach, he would rebuild his lesson plan. If the score of his students were less than the passing grade (KKM), he conducted the next cycle. 


\section{DISCUSSION}

Implementation of Teaching British Parliamentary Debate through Android Application, Video, and PowerPoint Presentation

1. Cycle 1

a. Planning

In the planning, the researcher prepared syllabus (British Parliamentary Debate), prepared lesson plan (British Parliamentary Debate), teaching materials (Introduction to British Parliamentary Debate), and media (a YouTube video, slides of PowerPoint Presentation, and Android Application). The teacher used a YouTube video (Introduction to British Parliamentary Debate). The PowerPoint Presentation also was about (Introduction to British Parliamentary Debate). The teacher chose to use Android application (Debate Assistant). This was the first meeting for the students learn about the British Parliamentary Debate, so the teacher prepared the materials about "Introduction to British Parliamentary Debate". The teacher prepared rubric (Scoring of speaking). The teacher would assess the students from four aspects. There were pronunciation, grammatical accuracy, vocabulary, and fluency. The range of the score was from 20 to 100 .

\section{b. Implementation of the Action}

The cycle 1 started from 19, 21, and 26 April 2016. This cycle divided into three parts. The first part, the researcher conducted pre-test on 19 April 2016. The motion was "This house would ban homework". The researcher gave flashcards. In the flashcard included the motion and questions. In the pre-test, some students got difficulties. Most of the students were difficult to say /'stju:dnt/. The written word is /student/. However, they pronounced/setadent/. Some students used code mixing Indonesia and English - when they lost some words, for example: Students can membawa book. (Students can bring book.) Some students did not understand the meaning of questions, for example: Most of the students did not understand the meaning of "advantages and disadvantages". Therefore, the researcher needed to give clues of the meaning of the questions. 
The second part, the researcher conducted treatment. On 21 April 2016, the researcher and observer came to the class. Before the class started, the researcher introduced the observer. After that, the researcher started his class. The teacher and students prayed together. The teacher checked attendance list of students. The teacher explained the topic of the meeting. They learned about the British Parliamentary Debate. The teacher played video about "Introduction to British Parliamentary Debate". The students observed the video and prepared their question about the British Parliamentary Debate. The video was played from beginning until ending without the teacher paused the video. In the questioning state, none of the students gave questions to the teacher. Then, the teacher continued the materials. The teacher divided the students into some groups. The teacher distributed hand out of PowerPoint Presentation (PPT), and he displayed PPT on the screen. The title of PPT was "Introduction to British Parliamentary Debate". Some students gave questions about British Parliamentary Debate. The teacher shared "Debate Assistant" to the students. The students installed "Debate Assistant" in their smart phones. The teacher explained how to use "Debate Assistant". The teacher launched the motion about "This house would ban school students from having smart phones" to practice debate. The teacher divided the students into 4 groups. Each group consisted two debaters. The students started case building. The teacher, observer, and students went out of the class and they started debate outside of the class. The students started their debate. At the end of debate, the teacher gave feedback and motivation to his students.

The third part, the researcher conducted post-test on 26 April 2016. The motion was "This house believes motivation is more important for success than intelligence". There was little improvement from pre-test. In the pre-test, some students got difficulties. Most of students were difficult to pronounce the written word /student/, and they pronounced /setadent/. When they remembered correct pronunciation, they pronounced /'stju:dnt/. Before the teacher reminded the correct pronunciation to say /'stju:dnt/ in the pre-test and treatment, the students tried to change their habit to say /setadent/. Some students used code mixing - Indonesia and English - when they lost some words, for example: We don't have in Bahasa teralalu kaku to think our success. (We don't have in Bahasa Indonesia too formal to think our success.) 
Therefore, in the cycle 1 , most of the students were still adapted with the process of this study.

\section{c. Observation}

In the cycle 1 , the teacher and observer observed the teaching and learning process. The teacher prepared two observational checklist for the teacher and students. First, the result of the teacher's observational checklist, the teacher forgot to remind the students about previous lesson. The method of the teacher was scientific approach to teach his students. There are observing, questioning, collecting information, associating, and communicating. In observing, the teacher ordered to the students to observe the video about "Introduction to British Parliamentary Debate". The problem happened in questioning. The teacher gave chance to the students to give questions about the material, but none of the students gave question in questioning section. However, they gave questions in collecting information.

Second, the result of the students' observational checklist, the students watched the video, but they did not analyze it. None of the students wrote down information from the video. After they watched the video, the teacher gave opportunities to ask question. However, none of the students gave question. They were still confused with the materials. They did not get the idea after they watched video. The teacher distributed the materials, and the students discussed about the materials with their groups. After the teacher explained the PowerPoint Presentation, the students gave questions to the teacher. When the students practiced the British Parliamentary Debate, only one student gave Point of Information (POI). The students did not feel confident to give (POI). They were still adapted how to deliver and receive POI.

\section{d. Reflection}

From the cycle 1, the researcher could reflect that the students were still confused with the rules of British Parliamentary Debate. The teacher played video without giving clues, and it made students confused about the materials. The observer suggested to the researcher to give clue or little explanation while video was played. Therefore, the students could focus on video, and they could prepare their questions. The teacher ordered to the students to analyze and write down their comments or 
questions whilst video was played. The researcher though that the groups consisted of four members in the discussion were not effective. The situation of the class was in the language laboratory, so the group discussion did not work well. The researcher would change into peer to peer. One group consisted two students. Only one student gave Point of Information (POI), so the researcher and observer agreed to make regulation. The students were obliged to give two POIs and received one POI minimally. The passing grade (KKM) was 72 . The target of the passing grade was $85 \%$, but only $36.36 \%$ from the students could reach the target. The students did not achieve the target of the passing grade in the pre-test and post-test of cycle 1 . Therefore, the researcher would conduct the cycle 2 to achieve the target of the passing grade.

\section{Cycle 2}

\section{a. Planning}

The researcher planed back cycle 2. The teacher would show video about the students' performance in the debate. The teacher gave clue while video was played. The students needed to evaluate themselves or their friends. They could write down their comment after the video had done. They could deliver their comments about the video. Therefore, the students could evaluate themselves from the video. The feedback could be from the teacher or class feedback. The researcher changed the PowerPoint Presentation material about POI. Before the students started the discussion about POI, the teacher would divide the students into some groups. Each group consisted two members. The researcher gave PowerPoint Presentation about POI to reinforce the students how to deliver and receive the POI.

\section{b. Implementation of the Action}

The cycle 2 started from 28 April, 3 and 5 May 2016. The cycle 2 divided into three parts. The first part, the researcher conducted pre-test on 28 April 2016. The motion was "This house believes social networking increases social problems among teenagers". Before the teacher suggested giving main utterance than supporting utterance, some students used it. It illustrated below:

Question : Do you agree or disagree with the motion? 
The student $\quad$ : I disagree with our motion today. I will give three point of view from first from teenagers, second from advance technology, and third from manner of teenagers.

Therefore, the researcher concluded that the students used their method in debate when they answered the question. It made the listener easy to catch their ideas, and it made the students easy to deliver their ideas.

The second part, the researcher conducted treatment. On 3 May 2016, the researcher and observer came to the class. The teacher and students prayed together. The teacher checked attendance list of students. The teacher played the students' debate practice video that took from previous meeting. The students observed the video and prepared their question about the British Parliamentary Debate. The students wrote down their comment or question in a piece of paper. The teacher played video. Sometimes, the teacher paused the video and gave the clue from video. The video finished. Some students gave question to the teacher. The teacher distributed the materials and showed the slides. Before the teacher explained the materials, the students discussed the materials. The teacher discussed and explained the material about POI. The teacher found a motion from Debate Assistant, and the motion was "This house believes that Facebook is a reflection of urban loneliness". The students started case building. After case building, they started the debate and used the Android application. At the end, the teacher gave feedback, verbal, and motivation for the students.

The third part, the researcher conducted post-test on 5 May 2016. The motion was "This house believes the internet brings more harm than good". The pronunciation problem of the written word of /student/ was difficult to be corrected by the teacher. One student were difficult to pronounce /'stju:dnt/, and he said /setaden/. The teacher reminded him to say /'stju:dnt/, but he could not change him habit. He was less practice to speak English. On the other hand, his friends who said /setanden/ in the cycle 1 tried to pronounce /'stju:dnt/. When they used code switching or mixing - Indonesia and English -, the students decreased their intensity, for example: ... some pelajaran ... Oh, I mean some lesson ...

\section{c. Observation}


In the cycle 2, the teacher and observer observed the teaching and learning process. The teacher prepared two observational checklist for the teacher and students. First, the result of the teacher's observational checklist, the teacher fixed some problems in the cycle 1 . The teacher reminded the students about previous lesson. The method of the teacher was scientific approach to teach his students. It was same with the cycle 1 . The teacher paused the video, and he gave the clue of the video. When the teacher opened question section, the students were enthusiast to give comments and questions. In the discussion, the students also gave questions about POI. At the end, the teacher forgot to give the next motion.

Second, the result of the students' observational checklist, the students watched the video, and they analyzed and took a note. After they watched the video, the teacher gave opportunities to give question. The students gave comment and question about their performance. The teacher distributed handouts about POI, and the students had discussion with their group. When the students practiced the British Parliamentary Debate, some of the students still read their notes while they were delivering their ideas. In the debate, the debater allowed to use note. However, the score of manner would be decrease by the adjudicators. The debaters tried to give POI, but it was given over the limited times.

\section{d. Reflection}

The cycle 2 had done well. The teacher fixed some problems in the cycle 1 . The teacher forgot to give the next motion at the end of the lesson. The teacher needed to read again the lesson plan before he taught in the class. When the students practiced the British Parliamentary Debate, some of the students still read their notes while they were delivering their ideas. The perceptions of the audiences and adjudicators thought that the debaters' speaking proficiencies were powerless. Therefore, the score of manner would be decreased by the adjudicators. In the debate, the debater allowed to use note. The teacher could give suggestion to the students to make key word in their notes. Therefore, the students did not read all arguments from their notes. The debaters tried to give POI, but it was given over the limited times. The debaters had 15 seconds maximally to give POI. One debater could give more than one POI. Something bad happened in the cycle 2. The video recorded when the students 
practiced debate was corrupted. It could not be played, evaluated, and shared with the students. From $85 \%$ target of the passing grade, $72.73 \%$ from the students achieved the target. Therefore, the students did not achieve the target in cycle 2, and the researcher would continue to achieve the target in cycle 3.

\section{Cycle 3}

\section{a. Planning}

The materials of the cycle 3 were difference. The video was the international debate competition "SWC Debate Final Round Part 5". The title of PowerPoint Presentation was "Basic Debating Skills". It was about manner, matter, and method.

The observer suggested encouraging students to be confident with their idea, so the students were less to read their notes. They could speak their idea without using the note. The researcher thought that the students could make keyword on their notes because the regulation did not avoid the debater to use a note. Therefore, the teacher did not only give the motivation but also give the solution.

The students forgot that they had limited time to deliver POI. The teacher needed to remind the students about the regulation before the debate started. The researcher prepared two cameras to solve the video problems. Therefore, he got complete the data.

\section{b. Implementation of the Action}

The cycle 2 started from 12 and 26 May, and 9 July 2016. This cycle divided into three parts. The first part, the researcher conducted pre-test on 12 May 2016. The motion was "This house would ban beauty contests". The students quoted some fact from online newspaper and it made their arguments stronger, for example: From Kompas.com, in Sweden, Vera Natali suicide because she does not win in the beauty contest. The students divided their arguments into some points, for example:

Question : What are the bad effects of beauty contests?

The student : I will peel the bad effects of beauty contest from two point of view of human right and social.

The second part, the researcher conducted treatment. On 26 May 2016, the researcher and observer came to the class. The teacher started class. The teacher explained the topic of the materials. They learned about matter, manner, and method. 
Before they learned matter, manner, and method, the teacher reminded previous materials. The teacher gave questions, and the students answered. The teacher played video about the real debate competition. The students needed to observe about the style and the method to deliver arguments from the video. The students needed to give commentary about it. The teacher played video. Sometimes, the teacher paused the video and gave the clue from video. The teacher gave clue about the video. When the video finished, the students started to give question and comment about the video. The teacher distributed the handouts and showed the slides. The students discussed the material with their partner. The teacher discussed and explained the material about matter, manner, and method. The teacher launched the motion about "This house believes that the beauty industry does more harm than good" The students started case building. After case building, they started the debate and used the Android application. At the end, the teacher gave feedback, verbal, and motivation for the students.

The third part, the researcher conducted post-test on 5 May 2016. The motion was "This house would ban cosmetic surgery". In the last cycle, the students decreased to use code mixing or switching - Indonesia and English -, and they practiced to speak English without mixed. The students were difficult to pronounce the written word of /surgery/. Some students said /surgery/. The correct pronunciation is /'s3: dzri/. The teacher gave the feedback to say /'s3:dzri/, but the students were still difficult to say it. They were consistent to divide their arguments in to some points. They brought their style in the debate when they answered the questions. To prove their arguments, some students quoted the fact from online newspaper. Therefore, they delivered one argument, and they proved the argument with examples. Then, they continued their arguments. Some students used jokes, and it was like on the debate. They used jokes to make the audience interesting with their arguments. To increase their speaking proficiency, the students needed to add their vocabularies, to practice pronunciations, and to practice grammatical accuracy. However, the students were significant improve their speaking skills from cycle 1, cycle 2, and Cycle 3.

c. Observation 
In the cycle 3 , the teacher and observer observed the teaching and learning process. The teacher prepared two observational checklist for the teacher and students. First, the result of the teacher's observational checklist, the teacher forgot to check attendance list when the class started. However, the teacher checked attendance list at the end of the class. When the teacher reminded previous material, the students forgot the previous material about POI. When the teacher gave clue, the students started reminding the materials. Before the debate started, the teacher reminded to the students about the rules how to deliver and receive POIs. Then, the teacher reminded times to give POI only 15 seconds. The teacher mentioned to the students to make short POI.

Second, the result of the students' observational checklist, the students said that they were difficult to get the message from the video. However, the teacher paused the video and gave short explanation. Therefore, the students could presume the message. Actually, from the video, the students needed to analysis how the debater delivered his arguments and his style. When the students practiced debate, POI was given by the debaters. However, the debaters were still in doubt to deliver it. Several of them did not give POIs.

\section{d. Reflection}

From the cycle 1 until cycle 3, some of the students did not give POIs because they were confused and afraid to give POIs. Actually, in one team, the debaters could share their POIs with their partners. The debaters wrote down their POIs in sticky note, and they shared it with their partners. However, some of the students did not use this opportunity. The passing grade (KKM) was 72 , and the target was $85 \%$. $90.91 \%$ of the students could pass the passing grade. The result of the post-test in cycle 3 was more than the target of the passing grade. Therefore, the students achieved the target of the passing grade, so the researcher stopped the study until cycle 3 .

Improvement of Teaching British Parliamentary Debate through Android Application, Video, and PowerPoint Presentation at English Debate Club in SMK N2 to Improve the Students' Speaking Skills 
In this study, the researcher and observer elaborated to collect scores of the students. Then, the researcher calculated the scores from the researcher and observer.

\section{Cycle 1}

Table 2 Count of Passing Grade of Pre-test in Cycle 1

\begin{tabular}{|c|c|c|}
\hline Criteria & Grade & Presentation \\
\hline$>72$ & 1 & $9.09 \%$ \\
\hline 72 & 0 & $0.00 \%$ \\
\hline$<72$ & 10 & $90.91 \%$ \\
\hline Total & 11 & $100.00 \%$ \\
\hline
\end{tabular}

From the data, the researcher knew that only one student could pass the passing grade (KKM) in the pre-test in cycle 1. The passing grade of English lesson in SMK N 2 Salatiga was 72 . The target presentation of passing grade was $85 \%$. Therefore, the target presentation of passing grade was not achieved.

Table 3 Grade of Passing Grade of Post-test in Cycle 1

\begin{tabular}{|c|c|c|}
\hline Criteria & Grade & Presentation \\
\hline$>72$ & 4 & $36.36 \%$ \\
\hline 72 & 0 & $0.00 \%$ \\
\hline$<72$ & 7 & $63.64 \%$ \\
\hline Total & 11 & $100.00 \%$ \\
\hline
\end{tabular}

From the data, there was improvement from the pre-test. The presentation of passing grade of pre-test was $9.09 \%$, and the passing grade in post-test was $36.36 \%$. However, the target presentation of passing grade was $85 \%$. Therefore, the target presentation of passing grade was not achieved in cycle 1 . The researcher would conduct the cycle 2 .

$M D=\frac{\sum D}{N}=\frac{34.625}{11}=3.15$

$S E_{M_{D}}=\frac{S D_{D}}{\sqrt{N-1}}=\frac{9.95}{\sqrt{11-1}}=\frac{9.95}{\sqrt{10}}=\frac{9.95}{3.16}=3.15$

$t_{o}=\frac{M_{D}}{S E_{M_{D}}}=\frac{3.15}{3.15}=1$ 
T-test was 1 . It used the significant level of $5 \%$ and t-table with $(\mathrm{N}-1)=10$ was 2.23. From the data, the researcher could conclude that the score of t-test was lower than t-table. Therefore, there was little significant improvement of the study.

2. Cycle 2

Table 4 Grade of Passing Grade of Pre-test in Cycle 2

\begin{tabular}{|c|c|c|}
\hline Criteria & Grade & Presentation \\
\hline$>72$ & 5 & $45.45 \%$ \\
\hline 72 & 0 & $0.00 \%$ \\
\hline$<72$ & 6 & $54.55 \%$ \\
\hline Total & 11 & $100.00 \%$ \\
\hline
\end{tabular}

From the data, there was little improvement from the post-test in cycle 1. From 4 students, the students who could pass the passing grade was 5 students in the pre-test of cycle 2 . From the post-test in cycle 1,36.36\% of students could pass the passing grade. In the pre-test of cycle 2, the students who could pass the passing grade was $45.45 \%$.

Table 5 Grade of Passing Grade of Post-test in Cycle 2

\begin{tabular}{|c|c|c|}
\hline Criteria & Grade & Presentation \\
\hline$>72$ & 8 & $72.73 \%$ \\
\hline 72 & 0 & $0.00 \%$ \\
\hline$<72$ & 3 & $27.27 \%$ \\
\hline Total & 11 & $100.00 \%$ \\
\hline
\end{tabular}

In post-test of cycle 2 , there were 8 students who could achieve the passing grade. Therefore, it was $72.73 \%$. It improved from pre-test of cycle 2 . The presentation of students in pre-test of cycle 2 who could achieve the passing grade was $45.45 \%$. However, the target of the passing grade was $85 \%$. Therefore, the researcher would conduct the cycle 3 to achieve the target.

$$
\begin{aligned}
& M D=\frac{\sum D}{N}=\frac{14.38}{11}=1.31 \\
& S E_{M_{D}}=\frac{S D_{D}}{\sqrt{N-1}}=\frac{4.13}{\sqrt{11-1}}=\frac{4.13}{\sqrt{10}}=\frac{4.13}{3.16}=1.31
\end{aligned}
$$




$$
t_{o}=\frac{M_{D}}{S E_{M_{D}}}=\frac{1.31}{1.31}=1
$$

From the data in cycle 2 , the researcher could conclude that t-test was 1 , and t-table with $(\mathrm{N}-1)=10$ was 2.23 . The significant level was $5 \%$. Therefore, the score of t-test was lower than t-table. There was little significant improvement of the study.

3. Cycle 3

Table 6 Grade of Passing Grade of Pre-test in Cycle 3

\begin{tabular}{|c|c|c|}
\hline Criteria & Grade & Presentation \\
\hline$>72$ & 8 & $72.73 \%$ \\
\hline 72 & 1 & $9.09 \%$ \\
\hline$<72$ & 2 & $18.18 \%$ \\
\hline Total & 11 & $100.00 \%$ \\
\hline
\end{tabular}

In the pre-test of cycle 3, 9 students could pass the passing grade. $72.73 \%$ students got more than 72 , and one student got 72 . Therefore, the total of the students who could pass the passing grade was $81.82 \%$. It closed the target of the passing grade.

Table 7 Grade of Passing Grade of Post-test in Cycle 3

\begin{tabular}{|c|c|c|}
\hline Criteria & Grade & Presentation \\
\hline$>72$ & 9 & $81.82 \%$ \\
\hline 72 & 1 & $9.09 \%$ \\
\hline$<72$ & 1 & $9.09 \%$ \\
\hline Total & 11 & $100.00 \%$ \\
\hline
\end{tabular}

The target of the passing grade was $85 \%$. The result was more than the target of the passing grade. The result of post-test in the cycle 3 was $90.91 \%$. 10 students could pass the passing grade. It increased from pre-test of cycle 3. There were 9 students. The target of the passing grade achieved by the students. Therefore, the researcher stopped the study until cycle 3.

$$
\begin{aligned}
& M D=\frac{\sum D}{N}=\frac{9}{11}=0.82 \\
& S E_{M_{D}}=\frac{S D_{D}}{\sqrt{N-1}}=\frac{1}{\sqrt{11-1}}=\frac{1}{\sqrt{10}}=\frac{1}{3.16}=0.32 \\
& t_{o}=\frac{M_{D}}{S E_{M_{D}}}=\frac{0.82}{0.32}=2.56
\end{aligned}
$$


From the data in cycle 3, the score of t-test was 2.56. The significant level was $5 \%$ to $t$-table. The score of $t$-table with $(\mathrm{N}-1)=10$ was 2.23 . The result was $2.56>2.23$. The researcher could conclude that the score of t-test was higher than t-table. The significant difference of the study was 0.33 . After the researcher repeated the cycles until three times, the researcher could conclude that teaching British Parliamentary Debate through Android application, video, and PowerPoint Presentation at English Debate Club in SMK N2 improved the students' speaking skills. Therefore, there was a significant difference between pre- and post-test mean in cycle 3. It meant that teaching British Parliamentary Debate through Android application, video, and PowerPoint Presentation influenced the students' speaking skill.

\section{CONCLUSIONS}

Implementation of Teaching British Parliamentary Debate through Android Application, Video, and PowerPoint Presentation

From this study, the researcher could conclude that the implementation of teaching British Parliamentary Debate through Android application, video, and PowerPoint Presentation at EDC in SMK was successful. The researcher got the information from cycle 1 , cycle 2 , and cycle 3 .

The researcher analyzed the speaking proficiency of the students, and they increased their speaking proficiency from cycle 1 until cycle 3 . The fluency of students increased from their practice in the class. In the cycle 1, none of the students delivered their arguments with systematic ways. In cycle 2 until cycle 3, they divided their arguments into some points. They used main utterance into supporting utterance. In the supporting utterance, they gave real example from their arguments. Therefore, the speaking proficiency of the students increased from time to time.

Improvement of Teaching British Parliamentary Debate through Android Application, Video, and PowerPoint Presentation at English Debate Club in SMK N2 to Improve the Students' Speaking Skills

From the data, the researcher can conclude that there is significance improvement teaching British Parliamentary Debate through Android application, video, and PowerPoint 
Presentation at EDC in SMK N 2 Salatiga. The researcher can prove it from data in cycle 1, cycle 2 , and cycle 3 . The passing grade of this study is 72 . The target is $85 \%$ from 11 students who join in the study.

In the cycle 1 , mean of the pre-test is 68.34 . On the other hand, mean of the post-test is 71.49. Mean post-test is higher than pre-test. Therefore, there is significance improvement. The significant level is $5 \%$ in this study. The result of t-test is 1 , and t-table is 2.23 . T-test is lower than t-table. Therefore, there is little significant improvement of the study. The presentation of passing grade of pre-test is $9.09 \%$, and it increases in post-test. The presentation of post-test is $36.36 \%$. However, the target is not achieved by the students. Therefore, the researcher conducts the cycle 2 .

In the cycle 2 , mean of the pre-test is 71.89 . On the other hand, mean of the post-test is 73.19. Mean post-test is higher than pre-test. Therefore, there is significance improvement. However, t-test was 1 , and t-table is 2.23 . T-test is lower than t-table. Therefore, there is little significant improvement of the study. The presentation of passing grade of pre-test is $45.45 \%$, and it increases in post-test. The presentation of post-test is $72.73 \%$. However, the target is not achieved by the students. Therefore, the researcher conducts the cycle 3 .

In the cycle 3, mean of the pre-test is 73.45 . On the other hand, mean of the post-test is 74.27. Mean post-test is higher than pre-test. Therefore, there is significance improvement. The significant level is $5 \%$ in this study, and t-table with $(\mathrm{N}-1)$ is 2.23 . The result of t-test is 2.56. T-test is higher than t-table. Therefore, there is significant improvement of teaching British Parliamentary Debate through Android application, video, and PowerPoint Presentation at English Debate Club in SMK N2 to improve the students' speaking skills. The presentation of passing grade of pre-test is $85 \%$, and it increases in post-test. The presentation of post-test is $90.91 \%$. Therefore, the target is achieved by the students. The presentation of the post-test is over the target $85 \%$. Therefore, the researcher stops the study until cycle 3 .

\section{REFERENCES}

Aclan, E. M., and Aziz, N. H. A. 2015. Why and How EFL Students Learn Vocabulary in Parliamentary Debate Class. Advances in Language and Literacy Studies, 6, 102113. http://dx.doi.org/10.7575/aiac.alls.v.6n.1p.102 
Aperio. 2015. Among top 100 applications for utilities on the Amazon app store!. Retrieved from https://play.google.com/store/apps/details?id=in.apeiro.debateassistant\&hl=in

Arsyad, A. 1997. Media Pengajaran. Jakarta: PT Raja Grafindo Persada.

Broughton, G., Brumfit, C., Flavell, R., Hill, P., and Pincas, A. 2003. Teaching English as a Foreign Language. London: Routledge.

Bull, G. L., and Bell, L. 2010. Teaching with digital video. Washington DC: International Society for Technology in Education.

Burnette, E. 2010. Hello, Android Introducing Google's Mobile Development Platform. USA: The Pragmatic bookshelf.

Corbeil, G. 2007. Can PowerPoint Presentations Effectively Replace Textbooks and Blackboards for Teaching Grammar? Do Students Find Them an Effective Learning Tool?. CALICO Journal, 24, 631-656. http://dx.doi.org/10.1558/cj.v24i3.631-656

Crawford, R. 2013. The ICT Teacher's Handbook Teaching, Learning and Managing ICT in

The Secondary School. London: Routledge.

Darcey, L. and Conder, S. 2010. Teach Yourself Android Application Development in 24 Hours. USA: SAMS.

Esteras, S. R., and Fabre, E. M. 2007. Professional English in Use ICT. Cambridge:

Cambridge University Press.

Harmer, J. 2001. The Practice of English Language Teaching. UK: Longman.

Harvey-Smith, N. 2011. The Practical Guide to Debating World Style/British Parliamentary Style. New York: Idebate Press.

Hopkins, D. 1993. A Teacher's Guide to Classroom Research Second Edition. Buchringhom: Open University Press.

Jose, A. 2015. Pengguna Smartphone di Indonesia Capai 55 Juta. Retrieved from http://techno.okezone.com/read/2015/09/19/57/1217340/2015-penggunasmartphone-di-indonesia-capai-55-juta

Kim, H. S. 2015. Using Authentic Videos to Improve EFL Students' Listening Comprehension. International Journal of Contents, 11, 15-24. http://dx.doi.org/10.5392/IJoC.2015.11.4.015 
Lodico, M. G., Spaulding, D. T., and Voegtle, K. H. 2006. Methods in Educational Research from Theory to Practice. USA: Jossey-Bass.

Marcovitz, D. M. 2012. Powerful PowerPoint for Educators Using Visual Basic for Applications to Make PowerPoint Interactive Second Edition. California: Libraries Unlimited.

Mustikasari, D.W. 2014. Students' Awareness of Characters Building in Writing Class. Salatiga: STAIN Salatiga Press.

Nation, I. S. P. and Newton, J. 2009. Teaching ESL/EFL Listening and Speaking. New York: Routledge.

Nunan, D. 2003. Practical English Language Teaching. Singapore: McGrawHill.

Smith, K. L. 2006. Effective Use of PowerPoint. Retrieved from http://fctl.ucf.edu/TeachingAndLearningResources/Technology/PowerPoint/index.p $\underline{\mathrm{hp}}$

Stephen, M. 2006. Presentation with PowerPoint Learning Made Simple. London: Elsevier. Yang, Y. J., and Che, P. C. 2015. Improving College Students English Learning with Dr. Eye Android Mid. TOJET: The Turkish Online Journal of Education Technology, 14, 101-109.http://www.tojet.net/articles/v14i2/14213.pdf 